\title{
Öğretmenlerin Bakış Açısından Okul Yöneticilerinin Öğretimsel Liderlik Yeterliklerinin Değerlendirilmesi
}

\author{
Zafer KIRAZ1
}

\begin{abstract}
Öz: Bu çalışmada farklı okul türlerinde görev yapan öğretmenlerin bakış açısına göre okul yöneticilerinin öğretimsel liderlik yeterliklerinin genel değerlendirmesinin yapılması amaçlanmıştır. Tarama modeline göre desenlenen araştırmada, alt amaçlar doğrultusunda hem tekil, hem de ilişkisel tarama gerçekleştirilmiştir. Araştırmaya 2021 yılında Türkiye'nin farklı bölgelerinde, farklı okul türlerinde ve farklı branşlarda görev yapan 252 öğretmen katılmıştır. Araştırma soruları kapsamında okul yöneticilerinin öğretimsel liderlik yeterliklerinin değerlendirilmesinde betimsel istatistik kullanılmıştır. Araştırma sonucunda, farklı okul türlerinde görev yapan öğretmenlerin bakış açısına göre okul yöneticilerinin öğretimsel liderlik becerilerine ilişkin davranışları ara sıra sergiledikleri görülmüştür. Ayrıca okul yöneticilerinin öğretimsel liderlik yeterliklerine yönelik elde edilen bulguların öğretmenlerin cinsiyetleri ve kişilik özellikleri bakımından anlamlı bir şekilde farklılaştı̆̆ı, buna karşılık öğretmenlerin eğitim durumu, çalıştığı okul türü, kıdem yıll, teknoloji okuryazarlık becerisi, akademik olarak kendini geliştirme çabası değişkenleri bakımından anlamlı bir farklılığın gözlenmediği sonucuna ulaşılmıştır. Okul yöneticilerinin öğretimsel liderlik yeterliklerini artırmaları için politika yapıcılar tarafından okul yöneticilerine yönelik yeni politikalar belirlenmesi önerilebilir.
\end{abstract}

Anahtar Sözcükler: Okul yöneticileri, Öğretimsel liderlik, Kişilik özellikleri

\section{Evaluation of Instructional Leadership Competencies of School Administrators from the Perspective of Teachers}

\begin{abstract}
The aim of this study is to make a general evaluation regarding the instructional leadership competencies of school administrators from the perspective of teachers working in different school types. In the current study, which was designed as survey method, both single and correlational survey methods were employed. 252 teachers in different branches, working in different regions and in different school types in Turkey in 2021 participated in the study. Descriptive statistics were used to evaluate the instructional leadership competencies of school administrators. According to the obtained results, it was determined that school administrators exhibited behaviors related to instructional leadership from time to time. The instructional leadership competencies of school administrators were found to differ significantly in terms of teachers' gender and personality traits. On the other hand, teachers' opinions didn't differ in terms of teachers' educational status, type of school they worked in, years of experience, technology literacy skill, and academic self-improvement effort. It is suggested that policy makers should determine new policies for school administrators in order to further increase their instructional leadership competencies.
\end{abstract}

Keywords: School administrators, Instructional leadership, Personality traits 
Literatürde eğitim sürecinin etkili yürütülmesi ve bunun nasıl gerçekleştirilebileceği konusunda aynı zamanda eğitimin nasıl ele alınacağı ve yönetileceğine dair çok çeşitli teknik, yöntem ve öneriler geliştirilmektedir. Okul bir yaşam alanıdır hem de eğitim ve öğretimin yapıldığı bir alan olarak birçok paydaşın işbirliği içinde çalışması gereken ortak bir yaşama alanıdır. Birçok bileşeni bünyesinde bulunduran yapısı nedeniyle okul, hem iç çevresi hem de dış çevresinin baskısı altında yer almakta ve bundan dolayı çok dinamik bir yapıyı oluşturmaktadır. Bileşen sayısının çokluğu okulun amaçlarında çeşitlilik yaratmaktadır. Amaçların çeşitliliği hem olumlu hem de olumsuz yönler oluşturmaktadır. Amaç çeşitliliği en başta okulda bütünleşme sorununu yaratmakta ve yönetim zorluğunu gündeme getirmektedir. Bu nedenle liderlik kavramı oldukça önemli hale gelmektedir. Okulun kaynaklarını ihtiyaçlar doğrultusunda etkili ve verimli kullanan ve yönetimde fark yaratan liderlerin bulunması aynı zamanda eğitim ve öğretim sürecinin etkililiğinin sağlanmasını da kolay hale getirebilmektedir. Dolayısıyla bir örgüt olarak okul, okulun tüm işgörenlerinin yönetimsel ve liderlik sorumluluklarını üstlenmelerini gerektirmektedir (Altunay, 2017; Beycioğlu ve Aslan, 2012; Moore, 2015). Günümüzde öğretimsel liderlik yeterliliğini okul bazlı düşündüğümüzde çoğu okul yöneticilerinin bu konudaki yeterliliği gerçekliği yansıtmamaktadır. Çünkü herhangi bir okul yöneticisinin her branş ile ilgili önemli düzeyde içerik bilgisine sahip olması beklenmektedir. Ancak öğretmenliğin tüm branşları düşünüldügünde okul yöneticilerinden böyle geniş bir içerik bilgisine sahip olmalarını beklemek çok mümkün olmamaktadır. Mümkün olduğunu varsayarsak bile söz konusu içerik bilgisi ve deneyimi ile öğretmenlere eğiticilik yapması yönetimsel süreçlerin yürütülmesinin yanında ciddi bir sorun olarak öne çıkmaktadır (Horng ve Loeb, 2010).

\section{Liderlik Kavramı}

Liderlik tarih boyunca tartışılan ve üzerinde bir görüş birliği sağlanamamış bir kavramıdır. Dolayısıyla liderlik tanımı da kişiden kişiye farklı bakış açıları ve farklı analizlere göre farklı biçimlerde tanımlanmıştır (Şişman, 2011). Günümüze kadar alan yazında liderlik ile ilgili birçok kitap ve makale yayınlanmış (Aslan, 2020; Coad ve Berry, 1998; Erçetin, 2000; Fiedler, 1996; Jaiswal ve Dhar, 2015; Kaya ve Yiğit, 2020; Özalp ve Öcal 2000; Şişman, 2011; Tahaoğlu ve Gedikoğlu, 2009) ve çeşitli boyutları ile üzerinde tartışılmıştır. Dolayısıyla (özellikle günümüzde) başka bilim alanlarında olduğu gibi yönetim biliminde de en çok tartışılan konuların başında lider ve liderlik kavramları gelmektedir (Çelik, 2011). Genel bir bakış ile liderlik bir kişi ile bir gurup arasındaki güç ve otoriteye dayalı ilişki olarak tanımlanabilir ya da başka bir tanım ile liderlik, belirli amaçları gerçekleştirmek için başkalarını yönlendirme (Özdemir, 2003) olarak tanımlanabilir. Lider, çok çeşitli güç ve ilişki kaynaklarına sahiptir. Dolayısıyla belirlenen amaçlar ve koyulan hedefler doğrultusunda örgütü, işgörenleri ya da grubu yönlendirmek için sahip olduğu bu güç ve otoriteye dayalı ilişkisini kullanır. Bununla birlikte lider olan kişinin, grubun diğer üyelerinden karizma, zeka, yetenek gibi özellikler açısından üstün olması gerekmektedir (Fiedler, 1996). Liderlik kavramı bir başka boyut ile tanımlanır ise, geleceğe dair kestirimler yapmayı, örgütün yaşaması ve varlığını sürdürebilmesi için gerçekçi hedefler belirlemeyi ve insanları da bunları gerçekleştirmek için seferber etmeyi içermektedir (Şişman ve Turan, 2004). Buradaki tanımlardan da anlaşılacağı üzere liderlik kavramı daha çok güç ile ilişkilendirilmiştir. Çünkü güç ve buna dayalı hiyerarşik yapı kapitalist sistem için oldukça önemlidir. Böylece kapitalist sistem için önemli olan sınıfsal yapı ve bu yapıların hangi güce, ne kadar sahip olacağı ve bunun kabulü oluşturulmaktadır.

\section{Okul ve Liderlik}

Bütün örgütler amaçlarına ulaşmak ister bu o örgütün yaşaması için oldukça önemlidir. Çünkü genel sistem kuramına göre bütün sistemlerin amacı yaşamaktır ve sistem bu amaç için birleşen, birbirine dayanan ve birbirini etkileyen parçaların oluşturduğu bir bütündür (Başaran, 2008). Bundan dolayı bir örgütü amaçlarına göre yaşatmak için örgütün her tür kaynaklarını (insan ve madde) en verimli biçimde kullanan, liderlik özelliklerine sahip yöneticilere ihtiyaç vardır.

Okul yöneticisinin amacı öncelikli olarak okulu örgütsel amaçları doğrultusunda yaşatmaktadır. Yöneticinin görevi daha çok okul içi ve okul dışı rollerden oluşsa da öğrencilerin akademik başarılarını artırmak için öğretmenlerin motivasyonunu yükseltmede gerekli çabayı göstermesi de önemli görülmektedir. Ayrıca yönetici diğer konularda olduğu gibi bu konuda da oldukça önemli bir sorumluluğa sahiptir (Glanz, 
Öğretmenlerin Bakış Açısından Okul Yöneticilerinin Öğretimsel...

2006). Dolayısıyla okul yöneticileri sadece okulun düzenli işleyişinden sorumlu değildir yani görevleri sadece öğretmenleri ve öğrencileri yönlendirme ve kontrol etmeden ibaret değildir, aynı zamanda yol gösterme ve çabaları destekleme gibi görevleri de vardır (Cunningham ve Cardeiro, 2003).

Öğretimsel liderlik daha çok öğrencinin akademik, kültürel ve sosyal yönden geliştirilmesi üzerinde durmaktadır. Okulda öğretimin nitelikli yürütülebilmesi için öğretmenlerin mesleki gelişimlerinin desteklenmesi, okul içinde etkili bir koordinasyonun sağlanması, öğrenci gelişimlerinin izlenmesi ve öğretimin denetlenip değerlendirilmesi oldukça önemlidir (Özdemir, 2018). Klasik bakış açısında bu görevleri yerine getirecek kişinin ise öğretim liderleri olarak okul müdürleri olduğu söylenebilir. Ancak liderliğin sadece okul müdürüyle özdeşleştirildiği bu bakış açısına karşılık son yıllarda giderek karmaşıklaşan okul ve toplumsal çevrede müdürün bu rolü tek başına üstlenmesinin zor olduğu da vurgulanmaktadır (Beycioğlu ve Aslan, 2012). Başka bir ifadeyle, okul müdürlerinin liderlik ve özellikle öğretimsel liderlik rollerini tek başına üstenemeyeceği dile getirilmektedir. Literatürde daha çok lider olarak okul müdürleri işaret edilmesine rağmen öğretmenlerin de lider olduğuna dair söylemler mevcuttur. Bu söylemler öğretmenlerin okullarda sadece bir uygulayıcı olmadıklarına, bunun yanında düşünen, araştıran, sorgulayan, mesleki bilgi ve becerilerini geliştiren birer profesyonel olduklarına dikkat çekerek öğretmenlerin liderliğine vurgu yapmaktadır. Dolayısıyla lider olarak öğretmenler de okuldaki karar alma süreçlerine bilgi, beceri ve uzmanlıklarıyla katılacak, eğitim-öğretim uygulamalarının geliştirilmesinde ön planda rol oynayabileceklerdir (Özdemir ve diğerleri, 2018).

Yönetim alanında bilgi birikiminin artması ile birlikte yeni araştırmalar yapılmaya başlanmıştır (Aslan, 2020; Jaiswal ve Dhar, 2015; Kaya ve Yiğit, 2020). Yapılan bu yeni araştırmalar ile birlikte okul yöneticilerinin liderlik davranışlarını daha bilimsel olarak incelenmesine yol açmıştır (Hallinger ve Murphy, 1985). Okul yöneticilerinin liderlik davranışlarının bilimsel olarak tanımlanmış olması aynı zamanda yönetim süreçlerin kavranmasını da kolaylaştırmaktadır. Bundan dolayı dünyada ve Türkiye'de okul yöneticilerinin gösterdikleri liderlik davranışları araştırma konusu olmuş ve incelenmiş, böylece araştırmaların sonucunda elde edilen bilgiler doğrultusunda yöneticilerle ilgili bazı ortak özellikler belirlenmiştir. Bu ortak özellikler okul yöneticilerinin sergiledikleri liderlik tiplerinin oluşmasını sağlamaktadır. Buna göre belirlenen okul yöneticilerinin liderlik türleri arasında; öğretimsel liderlik, karizmatik liderlik, etik liderlik, dönüşümcü liderlik, sürdürümcü liderlik, hizmetkâr liderlik, kültürel liderlik, stratejik liderlik, vizyoner liderlik ve süper liderlik yer almaktadır (Çelik, 2011; Şahin ve Demir, 2015).

\section{Öğretimsel Liderlik}

Günümüzde okul yöneticilerinin öğretimsel liderlik davranışına sahip olmaları oldukça önemli görülmektedir. Çünkü okulda üretilen hizmetin nitelikli olması öğretimsel liderlik ile ilişkilidir. Öğretimsel liderlik kavramı, 1970'li yılların sonlarında özellikle batılı ülkelerde yapılan araştırmalarla birlikte gündeme gelmiştir. Öğretim liderliği, okul yöneticilerinin, okulda beklenen hedeflere ulaşabilmek için hem kendisinin yerine getirmek durumunda olduğu, hem de kendisi dışındaki insanları etkileyerek onlar aracılığıyla yerine getirmesini sağladığı davranışlardır (Şişman, 2011). Çelik'e (2011) göre ise öğretimsel liderlik, öğrenci başarısını artırmak ve öğretmenler ile öğrenciler için gerekli olan öğrenme koşullarını oluşturmak amacıyla okul ortamının hem daha nitelikli hem de daha üretken bir duruma dönüştürülmesine yönelik çalışmaları içermektedir. Günümüzde yapılan araştırmalar gösteriyor ki etkili okulların yöneticileri öğretimsel liderlik davranışı göstermektedirler. Bu konuda Jhonson ve Snyder'in (1990) yaptıkları çalışmada etkili okul üzerinde önemli rol oynayan faktörlerden birinin güçlü öğretimsel liderlik olduğunu vurgulamıştır.

Öğretimsel liderlik, eğitim yöneticisinin personelin yetiştirilmesi, geliştirilmesi, eğitimin denetimi ve değerlendirmesi gibi bir dizi beceriyi kapsayan bir süreçtir. Bu süreçte bir yandan öğretmenlerin gereksinim duydukları eğitim ihtiyaçları karşılanıp gelişimlerine katkı sağlanırken diğer yandan eğitimin amacını gerçekleştirmek için denetim ve değerlendirmeler yapılmaktadır. Aynı zamanda öğretimsel liderlik, okul yöneticilerinin rehber, mentor ve model olmasını, okulun gelişimini taahhüt etmeyi de beraberinde getirmektedir (Prytula ve diğerleri, 2013). Okul yöneticilerinin öğretimsel liderliği çeşitli boyutlarda aktif işbirliği gerektirmektedir. Dolayısıyla okul müdürleri öğretmenler, eğitim hedefleri, öğretim programları, 
öğretim ve değerlendirmede aktif işbirliği oluşturması gerekmektedir. Öğretimsel liderlikte okul yöneticileri ve öğretmenler, öğretimsel görevlerin değerlendirilmesi, program ve personel geliştirmenin sorumluluğunu paylaşırlar (Marks ve Printy, 2003). Söz konusu bu liderliğin kendine özgü bazı özellikleri vardır. Bunlardan biri öğretimsel lider, uyumlu ve işbirliğine açık olmalıdır yani öğretmen ve öğrencilerle uyumlu ve işbirliği içinde çalışabilmeli, mevzuat ve eğitim öğretim programlarıyla ilgili gerekli bilgilere sahip olmalıdır (Şişman, 2011). Bundan dolayı öğretimsel liderlerin öğrenen liderler olmaları gerekmektedir. Öğrenen liderler, sürekli kendilerini yenilerler ve güncel bilgileri takip ederler. Öğretimsel liderlikte amaç öğretimin daha etkili yapılması ve geliştirilmesidir. Öğretimsel liderlik yaklaşımını uygulayan okul yöneticileri okul ve çevresini öğretimin daha etkin olması amacına yönelik düzenlerler. Okul yöneticileri, okul içindeki en önemli öğretimsel liderdir. Öğretimsel liderlik özelliklerine sahip bir okul yöneticisi hem akademik başarıda yüksek beklentilere sahiptir hem de bu hedefe ulaşmak için gerekli olan öğretim stratejilerine sahiptir (Glanz, 2006). Buradaki anlatımlara göre okuldaki sorumluluklar özelikle de öğretimin sorumluluğu sadece öğretmende bulunmamaktadır. Rehberlik yapmak, personeli geliştirmek ve öğretimi değerlendirmek sorumluluğu üzerinden düşünüldüğünde, okul yöneticilerinin de çeşitli sorumluluklarının bulunduğunu söylemek mümkündür.

Genel bir bakış açısıyla değerlendirilecek olursa, yöneticilerin yönetim becerilerinin uygulama sürecine dahil olan işgörenler tarafından daha doğru değerlendirilebileceği söylenebilir. Başka bir ifadayle yönetim becerisi uygulama sürecinde daha iyi anlaşılmakta ve bu niteliğin en doğru değerlendirilmesi ise bu yönetime tabii olan işgörenlerin algısının ortaya konulmasıyla sağlanabilir. Dolayısıyla, okul yöneticilerinin görev yaptıkları okulda sergiledikleri yönetim becerileri, bütün okul bileşenlerini özellikle de öğretmenleri doğrudan etkileyebilmektedir. Bu nedenle okul yöneticilerinin yönetim sürecinde öğretimsel liderlik davranışlarını sergileyip sergilemedikleri, eğer sergiliyorlarsa hangi düzeyde ve ne şekilde sergiledikleri öğretmenlerin gözünden daha iyi yorumlanabilir. Bu bağlamda alanyazın incelendiğinde, ilişkisel ve öğretmen görüşlerine dayanan farklı çalışmaların olduğu görülmektedir. Örneğin Altunay'ın (2017) yaptığı çalışmada öğretimsel liderlik rollerine ilişkin ortaöğretim öğretmenlerinin görüşlerinin belirlendiği, Yılmaz ve Kurşun'un (2015) çalışmalarında, öğretmenlerin akademik iyimserlik düzeyleri ile ilk ve ortaokul müdürlerinin öğretimsel liderlik davranışları arasındaki ilişkinin incelendiği, Gümüşeli'nin (1996) İstanbul'daki ilköğretim okullarında çalışan müdürler ve her okuldan iki öğretmen ile gerçekleştirdiği çalışmasında, okul müdürlerinin öğretimsel liderlik görevlerini yerine getirme düzeylerinin incelendiği, Şişman'ın (2011) çalışmasında ise okul müdürlerinin öğretimsel liderlik düzeylerinin Eskişehir il merkezindeki ilköğretim okullarında görev yapan öğretmenler üzerinden incelendiği görülmüştür. Mevcut araştırmada ise alanyazında yapıldığı görülen çalışmalardan farklı olarak, Türkiye'nin yedi bölgesinden ve farklı okul türlerinde görev yapan öğretmenlerden toplanan verilerle, okul yöneticilerinin öğretimsel liderlik becerileri çeşitli değişkenlerle birlikte ele alınarak büyük resmin görülmesi amaçlanmıştır. Dolayısıyla bu araştırmanın, hem okul yöneticilerinin yönetim becerilerinden öncelikli etkilenen bileşenlerden biri olan öğretmenlerin görüşlerine odaklanması nedeniyle hem de katılımcılarının Türkiye'nin farklı bölgelerinden hem farklı okul türlerinde hem de farklı düzeylerinde görev yapan öğretmenlerden oluşması nedeniyle alanyazına katkı sağlayacağı düşünülmektedir.

\section{Amaç}

Bu çalışmada farklı okul türlerinde görev yapan öğretmenlerin bakış açısına göre okul yöneticilerinin öğretimsel liderlik yeterliklerinin genel değerlendirmesi yapılmıştır. Bu amaç doğrultusunda aşağıdaki sorulara cevap aranmıştır.

1. Öğretmenlerin bakış açısına göre okul yöneticilerinin öğretimsel liderlik yeterlikleri açısından genel durumları nedir?

2. Farklı değişkenler bakımından (cinsiyet, eğitim durumu, çalıştığı okul türü, kıdem yılı, teknoloji okuryazarlık becerisi, akademik olarak kendini geliştirme çabası, kişilik özellikleri) öğretmenlerin görüşlerinde, okul yöneticilerinin öğretimsel liderlik yeterliklerine ilişkin anlamlı bir farklılık var midir? 
Öğretmenlerin Bakış Açısından Okul Yöneticilerinin Öğretimsel...

\section{Yöntem}

\section{Araştırma Modeli}

Öğretmenlerin bakış açısına göre okul yöneticilerinin öğretimsel liderlik yeterliklerinin değerlendirildiği bu çalışma tarama modelinde betimsel bir araştırmadır. Tarama modeli, geçmişte ya da halen var olan bir durumu var olduğu şekliyle betimlemeyi amaçlayan araştırma yaklaşımıdır (Karasar, 2014). Araştırmanın alt amaçlar doğrultusunda hem tekil hem de ilişkisel tarama gerçekleştirilmiştir. İlişkisel tarama araştırmaları, iki ya da daha fazla değişken arasında birlikte değişim varsa bunun derecesini belirlemeyi amaçlamakta ve değişkenler arasındaki ilişkinin araştırmacılar tarafından değişkenlere müdahale (manipüle) edilmeden incelenmesine olanak tanımaktadır (Fraenkel ve diğerleri, 2012).

\section{Katılımcılar}

Araştırma Türkiye'nin yedi bölgesinde görev yapan öğretmenler üzerinde gerçekleştirilmiştir. Araştırma katılımcılarının belirlenmesinde kolay örnekleme yöntemi kullanılmış ve araştırmaya, 2021 yılında farklı okul türlerinde görev yapan, farklı branşlardan 252 öğretmen katılmıştır. Kolay örnekleme yönteminde veriler, zaman, para ve işgücü dikkate alınarak araştırmacının kolayca ulaşabileceği bir örneklemden toplanmaktadır (Büyüköztürk ve diğerleri, 2016).

Araştırmaya katılanların demografik bilgileri Tablo 1'de verilmiştir.

Tablo 1. Katılımcilarn Demografik Bilgileri

\begin{tabular}{|c|c|c|c|}
\hline & & Frekans & Yüzde (\%) \\
\hline \multirow[t]{3}{*}{ Cinsiyet } & Kadın & 146 & 57.9 \\
\hline & Erkek & 106 & 42.1 \\
\hline & Toplam & 252 & 100.0 \\
\hline \multirow[t]{4}{*}{ Eğitim Durumu } & Lisans & 199 & 79.0 \\
\hline & Yüksek Lisans & 51 & 20.2 \\
\hline & Doktora & 2 & 0.08 \\
\hline & Toplam & 252 & 100.0 \\
\hline \multirow[t]{5}{*}{ Okul Türü } & Okul Öncesi Eğitim Kurumu & 9 & 3.60 \\
\hline & İlkokul & 96 & 38.1 \\
\hline & Ortaokul & 101 & 40.1 \\
\hline & Lise & 46 & 18.3 \\
\hline & Toplam & 252 & 100.0 \\
\hline \multirow[t]{7}{*}{ Kidem Y1lı } & 5 Yıla Kadar & 38 & 15.1 \\
\hline & 6-10 Y 11 & 64 & 25.4 \\
\hline & $11-15 Y_{11}$ & 56 & 22.2 \\
\hline & $16-20 Y_{11}$ & 40 & 15.9 \\
\hline & 21-25 Y1l & 34 & 13.5 \\
\hline & 26 Yildan Fazla & 20 & 7.9 \\
\hline & Toplam & 252 & 100.0 \\
\hline
\end{tabular}

Tablo 1'de ifade edildiği gibi araştırmaya katılan öğretmenlerin çoğunluğu kadındır $(\% 57,9)$. Yine katılımcı öğretmenlerin büyük bölümünün $(\% 79,0)$ lisans mezunu öğretmenlerden oluştuğunu, katılımcıların görev yaptıkları okul türüne baktığımızda en çok $(\% 40,1)$ ortaokullarda görev yapan öğretmenlerin yer aldığ görülmüştür. Araştırmaya katılan öğretmenlerin $(\% 45,5) 10$ yıl ve altında bir kıdeme sahip oldukları görülmektedir.

\section{Veri Toplama Aracı}

Araştırmada öğretmenlerin bakış açısına göre okul müdürlerinin öğretimsel liderlik yeterliklerini belirlemek amacıyla Bellibaş ve diğerleri tarafından 2016 yılında geliştirilen Öğretimsel Liderlik Ölçeği (PIRMS) araştırmacılardan gerekli izinler alınarak kullanılmıştır. Ölçek beşli Likert tipi (Hiçbir Zaman, Çok Seyrek, Ara Sıra, Çoğu Zaman, Her Zaman) 44 madde ve 9 alt boyuttan oluşmaktadır. Ölçeğin geçerlilik çalışması kapsamında madde analizi ve doğrulayıcı faktör analizi yapılmıştır. Gerçekleştirilen madde analizi sonucunda tüm maddelerin ayırtedicilik düzeyinin yeterli olduğu belirlenmiştir. Doğrulayıcı faktör analizi sonucunda, dokuz faktörlü yapının iyi uyum gösterdiği (RMSEA=0.054, WRMR=1.005, CFI=0.97, TLI=0.97) ve 
doğrulandığı, tüm maddelerin faktör yüklerinin 0.58 ile 0.95 arasında değiştiği, her bir boyutun birbirleriyle yüksek düzeyde korelasyon gösterdiği $(r=0.35$ ile $r=0.66)$ görülmüştür. Güvenirlik çalışması kapsamında ise Genellenebilirlik Kuramına dayalı güvenirlik katsayısı hesaplanmıştır. Buna göre ölçeğin tamamı için Genellenebilirlik Kuramına dayalı güvenilirlik katsayısı 0.99 hesaplanmış, ölçeğin alt boyutları için ise 0.95 ile 0.99 arasında değişen güvenirlik katsayısı hesaplanmıştır.

Araştırmada ayrıca öğretmenlerin kişisel bilgilerinin toplanması amacıyla kategorik ve sıralama düzeyinde 12 soru yer almaktadır. Bu sorular hazırlanırken alandan üç öğretim üyesinin görüşüne sunulmuştur. Uzmanlardan gelen dönütler sonrasında sorular üzerinde gerekli düzeltme ve düzenleme yapılmış ve veri toplama aracına son şekli verilmiştir. Uygulanan veri toplama aracı kişisel bilgilerin yer aldığı 12 soru ve öğretimsel liderlik ölçeğine ilişkin 44 madde bulunmaktadır. Uygulama sonrası öğretimsel liderlik ölçeğinin alt boyutlarına ilişkin hesaplanan Cronbach Alpha güvenirlik katsayısı 0.86 ile 0.96 arasında değişirken ölçeğin geneline ilişkin hesaplanan Cronbach Alpha güvenirlik katsayısının 0.97 olduğu görülmüştür.

\section{Veri Toplama Süreci}

Veri toplama süreci 2021 yılı Temmuz-Ağustos ayları içerisinde çevrimiçi olarak sosyal medya üzerinden gerçekleştirilmiştir. Oluşturulan veri toplama aracının elektronik versiyonu Google Documents uygulaması üzerinde hazırlanmış ve veri toplama aracına ait linkler popüler sosyal medya uygulaması olan Instagram üzerinden paylaşılmıştır. Ayrıca öğretmenlerin dahil oldukları WhatsApp gruplarında veri toplama aracına ait linkler paylaşılarak katılımcıların araştırmaya gönüllü olarak katılmaları sağlanmıştır. Çevrimiçi araştırma süreci yaklaşık üç hafta sürmüştür.

\section{Verilerin Analizi}

Verilerin analizinde öncelikle elde edilen veriler kontrol edilerek veri uyumsuzluğu veya tutarsılıl̆ğ açısından kontrol edilmiştir. Ayrıca ölçek boyutlarının ve ölçek genelinden elde edilen ortalama puanlara göre uç değerler kontrol edilmiştir. Bunun için ölçek boyutları ve ölçek geneline ilişkin z skorlarına bakılmış ve uç değerler incelenmiştir. Daha sonra ölçekten elde edilen puanların basıklık ve çarpıklık değerlerine bakılmıştır. Alanyazında normal dağılım için kabul görülen basıklık ve çarpıklık değerleri -1 ile +1 arasındadır. Ölçek puan ortalamalarının basıklık (-0.241) ve çarpıklık (-0.578) değerleri belirtilen değer aralığında olduğu görülmüştür (Huck, 2008). Ayrıca ölçek ortalama puanının normalliği Kolmogorov Simirnov testiyle incelenmiştir. Test sonucunda ölçek ortalama puanlarının dağllımının normal olduğu belirlenmiştir $(D(252)=.051, p>.05)$.

Araştırma soruları kapsamında okul müdürlerinin öğretimsel liderlik yeterliklerinin değerlendirilmesinde betimsel istatistik (frekans, yüzde, ortalama ve standart sapma) kullanılmıştır. Ayrıca öğretmenlerin bakış acısana göre okul yöneticilerinin öğretimsel liderlik yeterliklerine ilişkin genel durumlarını belirlemek üzere değerlendirme aralıkları belirlenerek çözümlenmiştir. Öğretmenlerin kişisel özellikler açısından kendilerine vermiş oldukları puanların değerlendirilmesinde ise alt-üst \%27'lik gruplar kullanılmıştır. Son olarak gruplar arası karşılaştırma için bağımsız örneklem $t$ testi ve tek yönlü varyans analizi (One Way Anova) testinden yararlanılmıştır. Analizler sonucunda anlamlı farklılık çıkması durumunda farklılığın hangi gruplar arasında olduğunu belirlemek için çoklu karşılaştırma testlerinden LSD çoklu karşılaştırma testi yapılmıştır.

\section{Bulgular}

Bu başlık altında araştırmada elde edilen bulgular alt amaçlara uygun olarak aşağıda sırasıyla verilmiştir.

\section{Okul Yöneticilerinin Öğretimsel Liderlik Yeterliklerine İlişsin Genel Durumları}

Öğretmenlerin bakış açısına göre okul yöneticilerinin öğretimsel liderlik yeterliklerine ilişkin 44 maddelik öğretimsel liderlik ölçeğine ilişkin genel durumları Tablo 2'de verilmiştir. 
Öğretmenlerin Bakış Açısından Okul Yöneticilerinin Öğretimsel...

Tablo 2. Okul Yöneticilerinin Öğretimsel Liderlik Yeterliklerine İlişkin Genel Durumları

\begin{tabular}{lccc}
\hline Alt Boyutlar & $\bar{X}$ & Ss & $\begin{array}{c}\text { Öğretimsel Liderlik Davranışı } \\
\text { Sergileme Sıklı̆̆ }\end{array}$ \\
\hline Okul İçin Hedefler Koyma & 3.33 & 1.05 & Ara Sıra \\
Okul Hedeflerini Paylaşma & 3.32 & 1.10 & Ara Sıra \\
Öğretimi Denetleme Ve Değerlendirme & 3.10 & 1.03 & Ara Sıra \\
Öğrenci Başarısını Takip Etme & 3.13 & 1.15 & Ara Sira \\
Öğretime Harcanan Zamanı Kontrol Etme & 3.35 & 0.94 & Ara Sıra \\
Okulda Görünür Olmak & 3.27 & 1.04 & Ara Sira \\
Öğretmenleri Teşvik Etme & 3.19 & 1.17 & Ara Sıra \\
Mesleki Gelişimi Desteleme & 3.32 & 1.19 & Ara Sıra \\
Öğrenmeyi Teşvik Etme & 3.52 & 1.16 & Çoğu Zaman \\
Öğretimsel Liderlik Ölçeği Geneli & 3.28 & 0.97 & Ara Sira \\
\hline
\end{tabular}

Tablo 2'de görüldüğü üzere farklı okul türlerinde görev yapan öğretmenlerin bakış açısına göre okul yöneticilerinin öğretimsel liderlik ölçeği ortalamaları 3.28'dir. Buna göre okul yöneticileri öğretimsel liderliğe ilişkin davranışları genel olarak ara sıra sergilemektedirler. Ölçek alt boyutları açısından değerlendirildiğinde ise; okul yöneticileri öğrenmeyi teşvik etme davranışlarını çoğu zaman, okul içi hedefler koyma, öğretimi denetleme ve değerlendirme, öğrenci başarısını takip etme, okulda görünür olma, okul hedeflerini paylaşma, öğretime harcanan zamanı kontrol etme, öğretmenleri teşvik etme ve mesleki gelişimi desteklemeye yönelik davranışları ise ara sıra sergiledikleri görülmektedir. Okul yöneticileri öğrenmeyi teşvik etme amacıyla daha çok olumlu davranışlar sergileyen veya akademik başarı gösteren öğrencileri motivasyonlarını artırmak ve onurlandırmak için toplantı ve törenlerde onlardan bahsetme ve başarılı öğrencileri okul gazetesinde bahsetme, kurdele verme, madalya gibi çeşitli yollarla ödüllendirdikleri görülmektedir. Öğretmenlerin görüşlerine göre okul yöneticileri en az öğretimi denetleme ve değerlendirmeye yönelik davranışlar sergilemekte, en çok ise öğrenmeyi teşvik etmeye yönelik davranışlar sergilemektedir.

\section{Öğretmenlerin Cinsiyetlerine Göre Okul Yöneticilerinin Öğretimsel Liderlik Yeterliklerine İlişkin Görüssleri}

Okul yöneticilerinin öğretimsel liderlik yeterliklerine ilişkin öğretmenlerin görüşlerinde cinsiyetleri açısından anlamlı bir farklılık olup olmadığı incelenmiş ve bulgular Tablo 3 ve Tablo 4'te sunulmuştur.

Tablo 3. Öğretmenlerin Cinsiyetlerine Göre Okul Yöneticilerinin Öğretimsel Liderlik Yeterliklerine İlişkin T testi Sonuçları

\begin{tabular}{lcccccc}
\hline Cinsiyet & $\mathrm{N}$ & $\overline{\mathrm{X}}$ & $\mathrm{S}$ & $\mathrm{Sd}$ & $t$ & $p$ \\
\hline Kadın & 146 & 3.17 & 0.96 & 250 & -2.146 & .033 \\
Erkek & 106 & 3.43 & 0.97 & & & \\
\hline
\end{tabular}

$t=-2.146 s d=250 \quad p<.05$

Tablo 3'te görüleceği üzere, öğretmenlerin cinsiyetlerine göre okul yöneticilerinin öğretimsel liderlik yeterlikleri anlamlı bir farklılık göstermektedir $[t(250)=-2.146, p<.05]$. Buna göre erkek öğretmenler okul yöneticilerinin öğretimsel liderlik yeterliklerine ilişkin görüşleri $(\bar{X}=3.43)$ ile kadın öğretmenlerin okul yöneticilerinin öğretimsel liderlik yeterliklerine ilişkin görüşleri $(\overline{\mathrm{X}}=3.17)$ istatistiksel olarak anlamlı bir farklılık göstermektedir. Bu bulgu, okul yöneticilerine ait öğretimsel liderlik yeterliklerinin erkek öğretmenler tarafından kadın öğretmenlere göre daha yüksek algılandığı şeklinde de yorumlanabilir.

Tablo 4. Ö̆gretmenlerin Cinsiyetlerine Göre Okul Yöneticilerinin Öğretimsel Liderlik Yeterlikleri Alt Boyutlarına İlişkin t Testi Sonuçları

\begin{tabular}{|c|c|c|c|c|c|c|c|}
\hline Boyutlar & Cinsiyet & $\mathrm{N}$ & $\overline{\mathrm{X}}$ & $S$ & Sd & $t$ & $p$ \\
\hline \multirow[t]{2}{*}{ Okullar İçin Hedef Koyma } & Kadın & 146 & 3.25 & 1.09 & 250 & -1.372 & .171 \\
\hline & Erkek & 106 & 3.43 & 0.98 & & & \\
\hline \multirow{2}{*}{ Okul Hedeflerini Paylaşma } & Kadın & 146 & 3.25 & 1.09 & 250 & -1.224 & .222 \\
\hline & Erkek & 106 & 3.42 & 1.11 & & & \\
\hline \multirow{2}{*}{ Öğretimi Denetleme Ve Değerlendirme } & Kadın & 146 & 3.05 & 0.99 & 250 & -1.079 & .282 \\
\hline & Erkek & 106 & 3.19 & 1.08 & & & \\
\hline \multirow[t]{2}{*}{ Öğrenci Başarısını Takip Etme } & Kadın & 146 & 3.07 & 1.17 & 250 & -0.993 & .322 \\
\hline & Erkek & 106 & 3.22 & 1.14 & & & \\
\hline Öğretime Harcanan Zamanı Kontrol & Kadın & 146 & 3.25 & 0.93 & 250 & -1.923 & .056 \\
\hline Etme & Erkek & 106 & 3.48 & 0.94 & & & \\
\hline
\end{tabular}




\begin{tabular}{|c|c|c|c|c|c|c|c|}
\hline \multirow[t]{2}{*}{ Okulda Görünür Olma } & Kadın & 146 & 3.16 & 1.02 & 250 & -2.050 & .041 \\
\hline & Erkek & 106 & 3.43 & 1.05 & & & \\
\hline \multirow[t]{2}{*}{ Öğretmenleri Teşvik Etme } & Kadın & 146 & 2.96 & 1.15 & 250 & -3.697 & .000 \\
\hline & Erkek & 106 & 3.50 & 1.13 & & & \\
\hline \multirow{2}{*}{ Mesleki Gelişimi Destekleme } & Kadın & 146 & 3.19 & 1.15 & 250 & -2.038 & .043 \\
\hline & Erkek & 106 & 3.49 & 1.22 & & & \\
\hline \multirow[t]{2}{*}{ Öğrenmeyi Teşvik Etme } & Kadın & 146 & 3.37 & 1.19 & 250 & -2.543 & .012 \\
\hline & Erkek & 106 & 3.74 & 1.10 & & & \\
\hline
\end{tabular}

$t=-2.050 s d=250 \quad p<.05, t=-3.697 s d=250 \quad p<.01, t=-2.038 s d=250 \quad p<.05, t=-2.543 s d=250 \quad p<.05$

Öğretimsel liderlik ölçeği alt boyutları açısından bakıldığında ise Tablo 4'te görüldüğü gibi okulda görünür olma $[t(250)=-2.050, p<.05]$, öğretmenleri teşvik etme $[t(250)=-3.697, p<.05]$, mesleki gelişimi destekleme $[t(250)=-2.038, p<.05]$ ve öğrenmeyi teşvik etme $[t(250)=-2.543, p<.05]$ alt boyutları açısından öğretmenlerin cinsiyetlerine göre anlamlı farklılık bulunmaktadır.

Diğer boyutlarda ise anlamlı farklılık bulunmamaktadır. Bu bulgu, okul yöneticilerine ait öğretmenleri teşvik etme, okulda görünür olma, mesleki gelişimi destekleme ve öğrenmeyi teşvik etme alt boyutlarına ilişkin erkek öğretmenler tarafından kadın öğretmenlere göre daha yüksek algılandığı şeklinde de yorumlanabilir.

\section{Öğretmenlerin Eğitim Durumuna Göre Okul Yöneticilerinin Öğretimsel Liderlik Yeterliklerine İlişkin Görüssleri}

Okul yöneticilerinin öğretimsel liderlik yeterliklerine ilişkin öğretmenlerin görüşlerinde eğitim durumları açısından anlamlı bir farklılık olup olmadığı incelenmiş ve bulgular Tablo 5'te sunulmuştur.

Tablo 5. Öğretmenlerin Eğitim Durumlarına Göre Okul Yöneticilerinin Öğretimsel Liderlik Yeterliklerine İlişkin t Testi Sonuçları

\begin{tabular}{lccc}
\hline Alt Boyutlar & $\bar{X}$ & Ss & $\begin{array}{c}\text { Öğretimsel Liderlik Davranışı } \\
\text { Sergileme Sıklığı }\end{array}$ \\
\hline Okul İçin Hedefler Koyma & 3.33 & 1.05 & Ara Sira \\
Okul Hedeflerini Paylaşma & 3.32 & 1.10 & Ara Sıra \\
Öğretimi Denetleme Ve Değerlendirme & 3.10 & 1.03 & Ara Sira \\
Öğrenci Başarısını Takip Etme & 3.13 & 1.15 & Ara Sıra \\
Öğretime Harcanan Zamanı Kontrol Etme & 3.35 & 0.94 & Ara Sira \\
Okulda Görünür Olmak & 3.27 & 1.04 & Ara Sira \\
Öğretmenleri Teşvik Etme & 3.19 & 1.17 & Ara Sira \\
Mesleki Gelişimi Desteleme & 3.32 & 1.19 & Ara Sira \\
Öğrenmeyi Teşvik Etme & 3.52 & 1.16 & Çoğu Zaman \\
Öğretimsel Liderlik Ölçeği Geneli & 3.28 & 0.97 & Ara Sira \\
\hline
\end{tabular}

Tablo 5'te görüleceği üzere, öğretmenlerin eğitim durumuna göre okul yöneticilerinin öğretimsel liderlik yeterlikleri anlamlı bir farklılık göstermemektedir $[t(250)=.477, p>.05]$. Öğretimsel liderlik ölçeği alt boyutları açısından da anlamlı farklılık bulunmamaktadır. Buna göre lisans mezunu öğretmenlerin okul yöneticilerinin öğretimsel liderlik yeterliklerine ilişkin görüşleri $(\bar{X}=3.30)$ ile yüksek lisans veya doktora mezunu öğretmenlerin okul yöneticilerinin öğretimsel liderlik yeterliklerine ilişkin görüşleri $(\bar{X}=3.22)$ istatistiksel olarak anlamlı bir farklılık göstermemektedir. Bu bulgu, okul yöneticilerine ait öğretimsel liderlik yeterliklerinin öğretmenlerin eğitim durumları açısından benzer algılandığı şeklinde de yorumlanabilir.

\section{Öğretmenlerin Çalıştı̆̆ı Okul Türüne Göre Okul Yöneticilerinin Öğretimsel Liderlik Yeterliklerine İlişkin Görüşleri}

Okul yöneticilerinin öğretimsel liderlik yeterliklerine ilişkin öğretmenlerin görüşlerinde çalıştığı okul türü açısından anlamlı bir farklılık olup olmadığı incelenmiş ve bulgular Tablo 6 ve Tablo 7de sunulmuştur.

Tablo 6. Öğretmenlerin Çalıştı̆̆ı Okul Türüne Göre Okul Yöneticilerinin Öğretimsel Liderlik Yeterliklerine İlişkin Puanların Aritmetik Ortalaması, Standart Sapması Ve Standart Hatasına İlişkin Sonuçlar

\begin{tabular}{lcccc}
\hline Çalıştığı Okul Türü & $\mathrm{N}$ & $\overline{\mathrm{X}}$ & Standart Sapma & Standart Hata \\
\hline A- Okul Öncesi Eğitim Kurumu & 9 & 3.20 & 0.99 & 0.33 \\
B- İlkokul & 96 & 3.29 & 0.89 & 0.09
\end{tabular}


Öğretmenlerin Bakış Açısından Okul Yöneticilerinin Öğretimsel...

\begin{tabular}{lcccc} 
C- Ortaokul & 101 & 3.39 & 0.97 & 0.10 \\
D- Lise & 46 & 3.03 & 1.10 & 0.16 \\
\hline
\end{tabular}

D- Lise

$46 \quad 3.03$

1.10

0.16

Tablo 7. Öğretmenlerin Çalıştı̆̆ı Okul Türüne Göre Okul Yöneticilerinin Öğretimsel Liderlik Yeterliklerine İlişkin Varyans Analizi Sonuçları

\begin{tabular}{|c|c|c|c|c|c|c|}
\hline Varyansın Kaynağı & $\begin{array}{l}\text { Kareler } \\
\text { Toplamı }\end{array}$ & Sd & Kareler Ortalaması & $F$ & $p$ & Anlamlı Fark \\
\hline Gruplararası & 4.066 & 3 & 1.355 & 1.441 & .231 & - \\
\hline Gruplariçi & 233.273 & 248 & .941 & & & \\
\hline Toplam & 237.339 & 251 & & & & \\
\hline
\end{tabular}

Tablo 6 ve Tablo 7 incelendiğinde öğretmenlerin çalıştığı okul türüne göre okul yöneticilerinin öğretimsel liderlik yeterlikleri istatistiksel olarak anlamlı bir farklılık göstermemektedir $[F(3-248)=1.441$, $p>$.05]. Başka bir deyişle okul yöneticilerinin öğretimsel liderlik yeterliklerine ilişkin öğretmen görüşleri, öğretmenlerin çalıştıkları okul türüne bağlı olarak anlamlı bir şekilde değişmemektedir. Bu bulgu, okul yöneticilerine ait öğretimsel liderlik yeterliklerinin öğretmenlerin çalıştıkları okul türü açısından benzer algılandığı şeklinde de yorumlanabilir. Kısaca okul yöneticileri farklı düzeylerdeki okullarda görev yapsalar da öğretmenler tarafından öğretimsel liderlik yeterlikleri aynı düzeyde algılamaktadırlar.

\section{Öğretmenlerin Kıdem Yılına Göre Okul Yöneticilerinin Öğretimsel Liderlik Yeterliklerine İlişkin Görüşleri}

Okul yöneticilerinin öğretimsel liderlik yeterliklerine ilişkin öğretmenlerin görüşlerinde kıdem yılı açısından anlamlı bir farklılık olup olmadığı incelenmiş ve bulgular Tablo 8 ve Tablo 9'da sunulmuştur.

Tablo 8. Öğretmenlerin Kıdem Yılına Göre Okul Yöneticilerinin Ö̆gretimsel Liderlik Yeterliklerine İlişkin Puanların Aritmetik Ortalaması, Standart Sapması ve Standart Hatasına İlişkin Sonuçlar

\begin{tabular}{lcccc}
\hline Kidem Yil1 & $\mathrm{N}$ & $\overline{\mathrm{X}}$ & Standart Sapma & Standart Hata \\
\hline A- 5 Yila Kadar & 38 & 3.32 & 0.91 & 0.15 \\
B- 6-10 Y1 & 64 & 3.48 & 0.99 & 0.12 \\
C- 11-15 Y11 & 56 & 3.17 & 0.93 & 0.12 \\
D- 16-20 Y1l & 40 & 3.26 & 1.00 & 0.16 \\
E- 21-25 Yil & 34 & 3.40 & 1.03 & 0.18 \\
F- 26 Y1l Ve Fazlasi & 20 & 2.74 & 0.88 & 0.20 \\
\hline
\end{tabular}

Tablo 9. Öğretmenlerin Kıdem Yılına Göre Okul Yöneticilerinin Ö̆̆retimsel Liderlik Yeterliklerine İlişkin Varyans Analizi Sonuçları

\begin{tabular}{lcccccc}
\hline \multicolumn{1}{c}{ Kareler } & & & & & Anlamlı Fark \\
Varyansın Kaynağ1 & Toplamı & Sd & Kareler Ortalaması & $F$ & - \\
\hline Gruplararası & 9.402 & 5 & 1.880 & 2.029 & .075 & \\
Gruplariçi & 227.937 & 246 & .927 & & \\
Toplam & 237.339 & 251 & & & \\
\hline
\end{tabular}

Tablo 8 ve Tablo 9 incelendiğinde öğretmenlerin kıdem yılına göre okul yöneticilerinin öğretimsel liderlik yeterlikleri istatistiksel olarak anlamlı bir farklılık göstermemektedir. [ $F(5-251)=2.029, p>.05]$ Başka bir ifadeyle, okul yöneticilerinin öğretimsel liderlik yeterliklerine ilişkin öğretmen görüşleri, öğretmenlerin kıdem yılına bağlı olarak anlamlı bir şekilde farklılaşmamaktadır. Bu bulgu, öğretmenler tarafından okul yöneticilerine ait öğretimsel liderlik yeterliklerinin öğretmenlerin kıdem yılı açısından benzer algılandığı şeklinde de yorumlanabilir. Ancak burada görülen önemli bir bulgu ise hem öğretimsel liderlik ölçeği geneli hem de alt boyutları açısından 26 yıl ve daha fazla mesleki kıdemi olan öğretmenlerin okul yöneticilerinin öğretimsel liderlik yeterliklerine ilişkin davranışları diğer gruplara göre en az sergilediğini belirtmeleridir. 


\section{Öğretmenlerin Teknoloji Okuryazarlık Düzeyine Göre Okul Yöneticilerinin Öğretimsel Liderlik Yeterliklerine İlişkin Görüşleri}

Okul yöneticilerinin öğretimsel liderlik yeterliklerine ilişkin öğretmenlerin görüşlerine göre teknoloji okuryazarlık düzeyleri açısından manidar bir farklılık olup olmadığı incelenmiş ve bulgular Tablo 10 ve Tablo $11^{\prime}$ de sunulmuştur.

Tablo 10. Öğretmenlerin Teknoloji Okuryazarlık Düzeylerine Göre Okul Yöneticilerinin Öğretimsel Liderlik Yeterliklerine İlişkin Puanlarm Aritmetik Ortalaması, Standart Sapması Ve Standart Hatasına İlişkin Sonuçlar

\begin{tabular}{lcccc}
\hline Teknoloji Okuryazarlık Düzeyi & $\mathrm{N}$ & $\overline{\mathrm{X}}$ & Standart Sapma & Standart Hata \\
\hline A- Düşük & 13 & 3.06 & 1.22 & 0.34 \\
B- Orta & 239 & 3.30 & 0.96 & 0.06 \\
C- Yüksek & 252 & 3.28 & 0.97 & 0.06 \\
\hline
\end{tabular}

Tablo 11. Öğretmenlerin Teknoloji Okuryazarlık Düzeylerine Göre Okul Yöneticilerinin Öğretimsel Liderlik Yeterliklerine Ilişkin Varyans Analizi Sonuçları

\begin{tabular}{|c|c|c|c|c|c|c|}
\hline Varyansın Kaynağı & $\begin{array}{l}\text { Kareler } \\
\text { Toplamı }\end{array}$ & $\mathrm{Sd}$ & Kareler Ortalaması & $F$ & $p$ & Anlamlı Fark \\
\hline Gruplararası & .673 & 1 & .673 & .711 & .400 & - \\
\hline Gruplariçi & 236.666 & 250 & .947 & & & \\
\hline Toplam & 237.339 & 251 & & & & \\
\hline
\end{tabular}

Tablo 10 ve Tablo 11 incelendiğinde öğretmenlerin teknoloji okuryazarlık düzeylerine göre okul yöneticilerinin öğretimsel liderlik yeterlikleri istatistiksel olarak anlamlı bir farklılık göstermemektedir. [F(1251)=.711, p>.05] Başka bir ifadeyle, okul yöneticilerinin öğretimsel liderlik yeterliklerine ilişkin öğretmen görüşleri, öğretmenlerin teknoloji okuryazarlık düzeylerine bağlı olarak anlamlı bir şekilde farklılaşmamaktadır. Bu bulgu, öğretmenler tarafından okul yöneticilerine ait öğretimsel liderlik yeterliklerinin öğretmenlerin sahip oldukları teknoloji okuryazarlık düzeyleri açısından benzer algılandığı şeklinde de yorumlanabilir.

\section{Öğretmenlerin Akademik Gelişim Çabalarına Göre Okul Yöneticilerinin Öğretimsel Liderlik Yeterliklerine İlişskin Görüşleri}

Okul yöneticilerinin öğretimsel liderlik yeterliklerine ilişkin öğretmenlerin görüşlerinde akademik olarak kendini geliştirme çabaları açısından manidar bir farklılık olup olmadığı incelenmiş ve bulgular Tablo 12 'de sunulmuştur.

Tablo 12. Öğretmenlerin Akademik Gelişim Çabalarnna Göre Okul Yöneticilerinin Öğretimsel Liderlik Yeterliklerine İlişkin t Testi Sonuçları

\begin{tabular}{|c|c|c|c|c|c|c|}
\hline $\begin{array}{l}\text { Akademik Gelişim } \\
\text { Çabası }\end{array}$ & $\mathrm{N}$ & $\overline{\mathrm{X}}$ & $S$ & $\mathrm{Sd}$ & $t$ & $p$ \\
\hline Evet & 172 & 3.30 & 1.02 & 250 & .411 & .681 \\
\hline Hayır & 80 & 3.24 & 0.88 & & & \\
\hline
\end{tabular}

Tablo 12'de görüleceği üzere, öğretmenlerin akademik gelişim çabasına göre okul yöneticilerinin öğretimsel liderlik yeterliklerine ilişkin görüşleri anlamlı bir farklılık göstermemektedir $[t(250)=.411, p>.05]$. Öğretimsel liderlik ölçeği alt boyutları açısından da anlamlı farklılık bulunmamaktadır. Buna göre akademik olarak kendini geliştirmek için çaba sarf eden öğretmenlerin, okul yöneticilerinin öğretimsel liderlik yeterliklerine ilişkin görüşleri $(\overline{\mathrm{X}}=3.30)$ ile akademik olarak kendini geliştirme çabası içerisinde olmayan öğretmenlerin okul yöneticilerinin öğretimsel liderlik yeterliklerine dair görüşleri $(\bar{X}=3.24)$ istatistiksel olarak anlamlı bir farklılık göstermemektedir. Bu bulgu istatistiksel olarak anlamlı fark çıkmamasına rağmen, akademik olarak kendini geliştirme çabası içerisinde olan öğretmenlerin böyle bir çaba içerisinde olmayan öğretmenlere göre okul yöneticilerinin daha az öğretimsel liderlik davranışı sergilediğini belirttiği şeklinde yorumlanabilir. 
Öğretmenlerin Bakış Açısından Okul Yöneticilerinin Öğretimsel...

\section{Öğretmenlerin Kişilik Özelliklerine Göre Okul Yöneticilerinin Öğretimsel Liderlik Yeterliklerine İlişkin Görüşleri}

Okul yöneticilerinin öğretimsel liderlik yeterliklerine ilişkin öğretmen görüşlerinde kişilik özellikleri açısından manidar bir farklılık olup olmadığ incelenmiş ve bulgular Tablo 13'te sunulmuştur.

Tablo 13. Öğretmenlerin Kişilik Özelliklerine Göre Okul Yöneticilerinin Öğretimsel Liderlik Yeterliklerine İlişkin t Testi Sonuçları

\begin{tabular}{|c|c|c|c|c|c|c|c|}
\hline Kişilik Özellikleri & & $\mathrm{N}$ & $\overline{\mathrm{X}}$ & $S$ & $\mathrm{Sd}$ & $t$ & $p$ \\
\hline \multirow[t]{2}{*}{ Dişadönüklük } & İçedönük & 68 & 3.12 & 0.92 & 134 & -1.416 & .159 \\
\hline & Dişadönük & 68 & 3.36 & 1.07 & & & \\
\hline \multirow[t]{2}{*}{ Yumuşak Başlılık } & Dikbaşlı & 68 & 3.10 & 1.00 & 134 & -2.378 & .019 \\
\hline & Yumuşak Başlı & 68 & 3.52 & 1.03 & & & \\
\hline \multirow[t]{2}{*}{ Öz-Denetim } & Düşük Öz-Denetim & 68 & 3.20 & 0.93 & 134 & -1.236 & .219 \\
\hline & Yüksek Öz-Denetim & 68 & 3.41 & 1.05 & & & \\
\hline \multirow[t]{2}{*}{ Duygusal Tutarsızlık } & Değişken Duygusal Durum & 68 & 3.22 & 1.07 & 134 & .288 & .774 \\
\hline & Tutarlı Duygusal Durum & 68 & 3.27 & 0.97 & & & \\
\hline \multirow[t]{2}{*}{ Gelişime Açıklık } & Yeniliğe Dirençli & 68 & 3.28 & 0.86 & 134 & -.563 & .574 \\
\hline & Gelişime Açık & 68 & 3.38 & 1.10 & & & \\
\hline
\end{tabular}

$t=-2.378 s d=134 \quad p<.05$

Öğretmenlerin kişilik özellikleri açısından okul yöneticilerinin öğretimsel liderlik yeterliklerine ilişkin görüşleri incelendiğinde Tablo 13'te görüldüğü gibi pozitif kişisel özellik sergileyen öğretmenler, sergilemeyenlere göre okul yöneticilerinin daha sık öğretimsel liderlik davranışı sergilediğini belirtmektedir. Ayrıca yapılan bağımsız örneklem $t$ testi sonucuna göre yumuşak başlılık kişilik özelliği açısından öğretmenlerin görüşleri arasında istatistiksel bakımdan manidar bir farklılık bulunmaktadır $[t(134)=-2.378$, $p<.05]$. Buna karşın, dışadönüklük, duygusal tutarsızlık, öz-denetim ve gelişime açılık kişilik özellikleri açısından öğretmenlerin görüşleri arasında istatistiksel olarak anlamlı farklılık bulunmamaktadır. Buna göre; hassas, çatışmadan kaçınan, merhametli, sakin, insanlara güvenen, geçimli veya işbirliğine yatkın olarak nitelendirilebilecek yumuşak başlı öğretmenlerin, işbirliğinden uzak, insanlara güvenmeyen, bağımsız, uyanık, mücadeleci veya şüpheci olarak nitelendirilebilecek dikbaşlı öğretmenlere göre okul yöneticilerinin daha sık öğretimsel liderlik davranışı sergilediği görüşünde olduğu söylenebilir.

\section{Sonuç ve Tartışma}

Araştırmada farklı okul türlerinde görev yapan öğretmenlerin bakış açısına göre okul yöneticilerinin öğretimsel liderlik yeterliklerinin belirlenmesi amaçlanmıştır. MEB Talim Terbiye Kurulu, okul yöneticilerinden beklenen rollerin birinin de öğretimsel liderlik rolleri olduğuna işaret etmektedir (Millî Eğitim Bakanlığı, 2005). Aynı zamanda okul yöneticilerinden öğretimsel liderlik rolleri sergilemelerini öğretmenler de beklemektedir. Ulaşılabilen alanyazında ülkemizde, okul yöneticilerinin öğretimsel liderlik yeterlikleri ve rolleriyle ilgili farklı boyutlarda çalışılmaların bulunduğu görülmektedir (Aksoy ve Işık, 2008; Aküzüm ve Taşdelen, 2015; Altunay, 2017; Argon ve Mercan, 2009; Beycioğlu ve Aslan, 2012; Buyrukçu, 2007; Gedikoğlu ve Tahaoğlu, 2009; Gülbahar ve Özdemir, 2019; İnand1 ve Özkan, 2006; İnceler, 2005; Özkaynak ve diğerleri, 2016; Yılmaz ve Kurşun, 2015).

Farklı okul türlerinde görev yapan öğretmenlerin bakış açısına göre okul yöneticileri öğretimsel liderliğe ilişkin davranışları genel olarak ara sıra sergilemektedirler. Ölçek alt boyutları açısından değerlendirildiğinde ise; okul yöneticileri öğrenmeyi teşvik etme davranışlarını çoğu zaman, diğer alt boyutlardaki davranışları ise ara sıra sergiledikleri görülmektedir. Şişman (2011) ise Öğretim Liderliği adlı çalışmasında söz konusu boyutların tamamında liderlik davranışlarına ilişkin ağırlıklı ortalamayı "çoğunlukla" şeklinde bulunmuştur. Bu araştırmada sadece bir tane alt boyutu çoğu zaman sergiledikleri görülürken, Şişman'ın araştırma sonuçlarına göre okul yöneticiler bütün alt boyutları çoğu zaman sergiledikleri görülmektedir. Okul yöneticilerinin öğrenmeyi teşvik etme davranışlarını sürekli sergilemeleri, günümüzde yaşanan Covid-19 pandemisinden dolayı yaklaşık iki yıl süren uzaktan eğitim süreci etkili olmuş olabilir. Çünkü uzaktan eğitim süreci öğrenciler ile birlikte öğretmenleri de oldukça yormuştur. Dolayısıyla uzaktan öğretim sürecinin nitelikli yapılabilmesi için okul yöneticileri öğretmenleri sürekli uzaktan eğitim 
sistemini ve öğretimini öğrenmeye teşvik etmiş olabileceklerini var sayabiliriz.

Öğretmenlerin görüşlerine göre okul yöneticileri en az öğretimi denetleme ve değerlendirmeye yönelik davranışlar sergilemektedir. Bu bulgu, Bilgin'in (2008) ile Gülbahar ve Özdemir'in (2019) yaptığı araştırma sonuçları ile uyum arz etmektedir. Her iki araştırmada, öğretmen algılarına göre okul yöneticilerinin en az sıklıkta gerçekleştirdikleri rollerin "denetleme ve değerlendirme" alt boyutundaki roller olduğu tespit edilmiştir. Dolayısıyla yapılan araştırmanın bulguları ile Özkaynak Topaçoğlu ve Şahin Fırat'ın (2016) yaptıkları İlköğretim Okul Müdürlerinin Öğretimsel Liderlik Davranışları isimli çalışmalarından elde ettikleri bulgulardan bir nevi farklılaşmaktadır. Çünkü söz konusu araştırmada öğretmenler için okul yöneticilerinin göstermesi gereken en önemli öğretimsel liderlik davranışı, okul yöneticilerinin okulun başarısını hedef alarak okulun amaçlarını öğretmen, öğrenci ve personeli de işin içine katarak ortak katılımla belirlemesi ve bunun devamlılığını sağlaması sonucuna ulaşılmıştır. Okul yöneticilerinin öğretimi denetleme ve değerlendirme öğretimsel liderlik rollerini diğer alt boyutlardaki rollerinden daha az sergiliyor olmalarının sebebi, ülkemizde her iş kolunda olduğu gibi eğitim iş kolunda da öğretmenlerin denetlemeyi olumsuz algıllyor olması ve bu durumdan rahatsızlık duymaları olabilir. Bundan dolayı okul yöneticileri öğretmenler ile çatışma yaşamamak için denetleme rolünü yerine getirmek istememeleri ve aynı zamanda yöneticilerin denetleme ve değerlendirmeye yeterince vakit ayırmamaları varsayılabilir.

Öğretmenlerin cinsiyetlerine göre okul yöneticilerinin öğretimsel liderlik yeterlikleri manidar bir farklılık göstermektedir. Bu bulgu, Yılmaz ve Kurşun'un (2015) yaptıkları araştırma sonucundan farklıdır. Çünkü söz konusu araştırmada okul yöneticilerinin öğretimsel liderlik yeterlikleri öğretmenlerin cinsiyetine göre anlamlı bir farklılık göstermemektedir. Bu iki sonuç arasındaki farklılığın nedeni araştırmaya katılan öğretmenlerin algılarının ve süreci kavramalarının zaman içerisinde değişime uğramış olabilmesi şeklinde yorumlanabilir. Liderlik ve yöneticilik patriarkal toplumlarda erkek ile özdeşleşmiştir. Dolayısıyla yönetici ya da lider denildiğinde ilk akla gelen erkek cinsiyeti olmaktadır. Ataerkil düşünce yapısı yıllar içerisinde her iki cinsiyeti de erkek egemen algı çerçevesinde dizayn etmektedir. Bu çerçevede çoğunlukla erkeklere yönetici olma (özellikle aileyi yönetme), kadınlara da itaat etme düşüncesi kazandırıldığını var sayabiliriz. Ayrıca Türkiye'de farklı okul türlerinde görev yapan yöneticilerin sayısı dikkate alındığında erkek yöneticilerin, kadın yöneticilerden oldukça fazla sayıda olduğu görülmektedir. Bundan dolayı araştırma sonucunda elde edilen cinsiyetler arasındaki manidar farklılık beklenen bir sonuç olarak değerlendirilebilir.

Öğretimsel liderlik ölçeği alt boyutları açısından bakıldığında, okulda görünür olma, öğrenmeyi teşvik etme, öğretmenleri teşvik etme ve mesleki gelişimi destekleme alt boyutları açısından öğretmenlerin cinsiyetlerine göre anlamlı farklılık bulunmaktadır. Bu bulgu Can (2014) ve Kurt (2020)'un yaptıkları araştırmalar ile mesleki gelişimi destekleme boyutunda benzerlik göstermektedir. Her iki araştırmada da mesleki gelişmeyi sağlama boyutunda öğretmen algılarının cinsiyete göre manidar bir farklılık gösterdiği tespit edilmiş, okul genelinde mesleki gelişmeyi sağlama boyutunda erkek öğretmenlerin kadın öğretmenlere göre daha yüksek bir algısının bulunduğu anlaşılmıştır. Diğer boyutlarda ise anlamlı farklılık bulunmamaktadır. Aydın'ın (2017) yaptığı araştırmada ise okul müdürlerinin öğretimsel liderliğin söz konusu alt boyutlarındaki davranışları ile görüşleri alınan öğretmenlerin cinsiyetleri arasında anlamlı bir farklılığa rastlanmamıştır. Aynı zamanda Deniz ve Erdener (2016) tarafından yapılan araştırmada ise okul müdürlerinin liderliğin söz konusu alt boyutlarındaki davranışları ile görüşleri alınan öğretmenlerin cinsiyetleri arasında kadın öğretmenlerin lehine anlamlı düzeyde farklılık görülmüştür. Farklı araştırmalarda farklı sonuçların çıkması öğretmenlerin bu konu ile ilgili algılarının sabit olmadığı, zaman içerisinde konu ile ilgili algılarının değiştiği şeklinde yorumlanabilir. Aynı zamanda araştırmanın liderlik ölçeği alt boyutları arasında cinsiyete göre anlamlı bir farklılığın bulunmasının, daha önce de bahsedildiği gibi, kadın ve erkeğin toplumsal cinsiyet rollerinin ve bu rollerin hem toplum hem de eğitim yolu ile nasıl ve ne şekilde kazandırıldığı ile ilgi olduğu çıkarımı yapılabilir.

Öğretmenlerin eğitim durumuna göre okul yöneticilerinin öğretimsel liderlik yeterlikleri anlamlı bir farklılık göstermemektedir. Öğretimsel liderlik ölçeği alt boyutları açısından da anlamlı farklılık bulunmamaktadır. Bu bulgu Şümür'ün (2021) araştırma bulgularından farklılık göstermektedir. Söz konusu araştırmada, okul hedeflerini paylaşma, okulda görünür olmak, öğretimi denetleme ve paylaşma, okul için 
hedefler koyma, mesleki gelişimi desteklemek alt boyutlarında ve öğretimsel liderlik ölçeği genel puanlarının eğitim durumları arasında farklılık gösterdiği tespit edilmiştir. Eğitim insanı geliştirmekte, ufkunu açmakta, olayları algılayış ve kavrayışını daha nitelikli hale getirmektedir. Dolayısıyla lisans mezununun ortaöğretim mezunundan, yüksek lisans mezunun lisans mezunundan ve doktora mezunun da yüksek lisans mezunundan daha iyi bir kavrayış ve yorumlayışa sahip olması beklenmektedir. Ancak okul yöneticilerinin öğretimsel liderlik yeterlikleri bakımından değerlendirilmesinde lisans, yüksek lisans ve doktora mezunu öğretmenler arasında bir farklılık bulunmaması, okul yöneticilerinin öğretimsel liderlik yeterliklerini çok boyutlu sergileyememesi nedeni ile öğretmenlerin söz konusu yeterlikleri algılayamamalarıly veya eğitim düzeyinin artmasının öğretmenlerin eleştirel bakış açısını çok etkilemediği ya da geliştirmediği şeklinde yorumlanabilir.

Öğretmenlerin çalıştığı okul türüne göre okul yöneticilerinin öğretimsel liderlik yeterlikleri istatistiksel olarak anlamlı bir farklılık göstermemektedir. Bu bulgu, Şümür'ün (2021) yaptığı çalışmada ulaşılan, öğretimsel liderlik ölçeğinin tüm alt boyutlarının ve genel puanlarının öğretmenin görev yaptığı okul türü bakımından farklılık gösterdiği yönündeki bulguyla farklılaşmaktadır. Oysaki öğretimsel liderlik yeterliklerinin bütün okul türlerinde görev yapan yöneticilerde benzer şekilde ortaya çıkması beklenmektedir. Dolayısıyla öğretmenlerin çalıştığı okul türüne göre okul yöneticilerinin öğretimsel liderlik yeterliklerini benzer şekilde göstermeleri, farklı okul türlerinde görev yapan okul yöneticilerinin aynı şekilde davranmaları yani okul türünün öğretimsel liderlik yeterliklerini ortaya çıkaran bir etken olmaması beklentiye uygun bir sonuç olarak değerlendirilebilir.

Okul yöneticilerinin öğretimsel liderlik yeterliklerine ilişkin öğretmen görüşleri, öğretmenlerin kıdem yılına bağlı olarak anlamlı bir şekilde farklılaşmamaktadır. Ancak burada görülen önemli bir bulgu ise, hem öğretimsel liderlik ölçeği geneli hem de alt boyutları açısından 26 yıl ve daha çok mesleki kıdemi olan öğretmenlerin, okul yöneticilerinin öğretimsel liderlik yeterliklerine ilişkin davranışları diğer gruplara göre en az sergilediğini belirtmeleridir. Bu durum 2000 yılından önce öğretmen olanların aldıkları formasyon ile ilişkilendirilebilir. Çünkü 1997 yılında öğretmen yetiştirme sistemimiz değiştirilmiştir. Yükseköğretim Kurulu'nun [YÖK], 04.11.1997 tarih ve 97.39.2761 no'lu kararıyla kabul edilen esaslar, 1998-1999 eğitim öğretim yılından itibaren uygulamaya konularak, eğitim fakültelerindeki kimi işlevsiz olduğu düşünülen bölümler kapatılarak, yeni bölümler açılması ve yeniden yapılandırılması yoluna gidilmiştir (YÖK, 1998). YÖK eğitim fakültelerinde yeni düzenlemeler yapma gereği duymuş ve öğretmen yetiştirme sisteminde bazı yenilik ve değişikliklerin gerekli olduğuna karar vermiştir. Dolayısıyla 1998 yılından önce öğretmenlik eğitimi alanlar ile bu tarihten sonra öğretmenlik eğitimi alanlar arasında olayları algılayış ve kavrayış açısından farklılıklar olduğunu söyleyebiliriz.

Okul yöneticilerinin öğretimsel liderlik yeterliklerine ilişkin öğretmen görüşleri, öğretmenlerin teknoloji okuryazarlık düzeylerine bağlı olarak anlamlı bir şekilde farklılaşmamaktadır. Teknoloji okuryazarlık düzeyinin öğretimsel liderlik yeterliklerinin belirlenmesinde ayrıt edici bir rol üstlenmesi beklenmesine rağmen bu çalışmada teknoloji okuryazarlı̆̆ına sahip olup olmamanın manidar bir farklılık yaratmadığı görülmektedir. Bunun sebebi teknoloji okuryazarlığına sahip olan öğretmenlerin bu özelliklerini olayları veya olguları değerlendirme süreçlerine yeterince transfer edemedikleri ve bu bilgilerini kullanmadıkları şeklinde yorumlanabilir.

Öğretimsel liderliğin hedefi öğretmenlere amaçlar belirleyerek, onlara rehberlik ederek, öğrencilerin gelişim süreçlerini yakından takip ederek okulun başarısını artırmaktır. Bu bağlamda akademik gelişim de bir bakıma öğrencilerin başarılı olabilmeleri için öğretmenlerin sürekli kendilerini geliştirme çabası olarak değerlendirilebilir. Aslında öğretimsel liderlik ile akademik gelişim çabası arasında bir bağ kurulabilir. Ancak araştırma bulgusuna göre akademik gelişim çabası içerisinde olan öğretmenler ile olmayan öğretmenler arasında okul yöneticilerinin öğretimsel liderlik yeterliklerine ilişkin görüşlerde manidar bir farklılık gözlenmemiştir. Her ne kadar akademik gelişim çabası içerisinde olan öğretmenlerin okul yöneticilerinin öğretimsel liderlik yeterliklerine ilişkin görüşleri böyle bir çaba içerisinde olmayan öğretmenlere kıyasla biraz daha yüksek olsa da bu durum öğretmenlerin akademik gelişimlerinde kendi öğretmenlik alanlarına daha çok yoğunlaştıklarını (İl̆an, 2013; Özdemir, 2016) ve bu durumu öğretimsel liderliğe ilişkin genel 
değerlendirmelerine yansıtmadıkları şeklinde yorumlanabilir.

Araştırma sonucunda pozitif kişilik özelliği (yumuşak başlılık, dışadönüklük, tutarlı duygusal durum, yüksek öz denetim, gelişime açıklık) sergileyen öğretmenler, sergilemeyenlere kıyasla okul yöneticilerinin öğretimsel liderliğe ilişkin yeterliklerini daha olumlu değerlendirmektedir. Bu araştırma sonucu, pozitif kişilik özelliğine sahip olanların, olmayanlara göre olumlu duygularını olumsuz duygularına kıyasla dışa vurmakta daha rahat oldukları ve daha olumlu değerlendirme yaptıkları şeklinde açıklanabilir. Çünkü pozitif kişilik özelliğine sahip olan bireylerin, olmayanlara göre daha dışa dönük ve kendilerini ifade etme becerisi bakamından daha yeterli olduklarını söyleyebiliriz. Bu çıkarımı destekler nitelikte, kişilik özellikleri ile ilgili yapılan pek çok çalışmada da (Atkinson ve diğerleri, 2010; Burger, 2006; Coşkun ve Aslan, 2021; Somer, 1998) bu konuyu açılayıcı sonuçların bulunduğu görülmektedir.

Araştırma sınırlılıkları ve bulgularına dayalı olarak uygulamaya ve gerçekleştirilecek araştırmalara ilişkin öneriler şu şekildedir;

- Araştırmada okul yöneticilerinin öğretimsel liderlik davranışlarını arasıra sergiledikleri sonucuna ulaşılmış, bundan dolayı okul yöneticilerinin öğretimsel liderlik yeterliklerini daha da artırmaları için politika yapıcılar tarafından okul yöneticilerine yönelik yeni politikalar belirlenebilir.

- Araştırmada öğretmenlerin akademik gelişim çabası içerisinde bulunsalar dahi söz konusu akademik gelişimlerini daha çok kendi öğretmenlik alanlarında kullandıkları ancak yöneticileri değerlendirme süreçlerine bu yeterliklerini pek aktaramadıkları görülmektedir. Bundan dolayı öğretmenlerin akademik gelişimlerini kendi öğretmenlik alanlarının dışında da kullanabilmeleri için hizmet içi eğitimlerin düzenlenmesi önemli görülmektedir.

- Araştırmada kişilik özelliklerinin okul yöneticilerinin öğretimsel liderlik yeterliklerine ilişkin algılarında farklılığa yol açabildiği görülmektedir. Bu farklılaşmanın nedenlerinin daha da derinlemesine inceleneceği nitel araştırmalar desenlenebilir.

- Okul yöneticilerinin öğretimsel liderliğe ilişkin yeterliklerini farklı paydaşlarının algılarına göre bütüncül olarak değerlendirileceği araştırmalar yapılabilir.

- Okul yöneticilerinin öğretimsel liderlik yeterliklerine etki eden psiko-sosyal değişkenlerin inceleneceği yapısal eşitlik araştırmaları gerçekleştirilebilir.

\section{Yazar(lar)ın Beyanı}

Araştırmacıların katkı oranı beyanı: Çalışmanın tamamı yazar tarafından yapılmıştır.

Etik Kurul Kararı: Çalışma Tokat Gaziosmanpaşa Üniversitesi Sosyal ve Beşeri Bilimler Araştırmaları Etik Kurulunun 16.09.2021 tarih ve 19. oturumda almış olduğu kararla etik açıdan uygun bulunmuştur.

Çatışma beyanı: Yazar potansiyel bir çıkar çatışması olmadığını beyan eder.

Destek ve teşekkür: Makaleye katkısı olan tüm katılımcılara teşekkür ederim.

\section{Kaynaklar}

Aksoy, E., \& H. Işık. (2008). İlköğretim okul müdürlerinin öğretim liderliği rolleri. Sosyal Bilimler Dergisi, 19, 235-249.

Aküzüm, C., \& Taşdelen, T. (2015). Öğretmen görüşleri açısından okul müdürlerinin öğretimsel liderlik davranışları. Turkish Studies -International Periodical for the Languages, Literature and History of Turkish or Turkic- 10(3), 1-26. https://doi.org/10.7827/TurkishStudies.7843

Altunay, E. (2017). Ortaöğretim öğretmenlerinin öğretimsel liderlik rollerine ilişkin görüşleri. Atatürk Üniversitesi Sosyal Bilimler Enstitüsü Dergisi, 21(2), 473-503.

Argon, T., \& Mercan, M. (2009, 3 Mayı). Illköğretim okulu yöneticilerinin öğretim liderliği rollerini gerçekleştirebilme düzeyleri [Konferans bildirisi]. I. Uluslararası Türkiye Eğitim Araştırmaları Kongresi, Çanakkale, Türkiye. 
Aslan, G. (2020). Investigation of the relationship between students' academic achievement and schools' leadership capacity: An analysis of lower secondary schools in Turkey, Kjep, 17(1), 43-66.

Atkinson, R. L., Atkinson, R. C., Smith, E. E., Bem, D. J., \& Nolen-Hoeksema, S. (2010). Psikolojiye giriş. (6. baskı). Arkadaş Yayınevi.

Aydın, M. (2017). Ortaöğretim müdürlerinin öğretim liderliği davranışlarının incelenmesi (Gaziantep örneği) [Yayımlanmamış yüksek lisans tezi]. Hasan Kalyoncu Üniversitesi.

Başaran, İ. E (2008). Türk eğitim sistemi ve okul yönetimi. Ekinoks yayınevi.

Bellibaş, M.S., Bulut, O., Hallinger, P., \& Wang, W.C. (2016). Developing a validated instructional leadership profile of Turkish primary school principals. International Journal of Educational Research 75, 115-133. https://doi.org/10.1016/j.ijer.2015.10.002

Beycioğlu, K., \& Aslan, B. (2012). Öğretmen ve yöneticilerin öğretmen liderliğine ilişkin görüşleri: Bir karma yöntem çalışması. Kuram ve Uygulamada Ĕ̆itim Yönetimi, 18(2), 191-223.

Bilgin, A. (2008). İlköğretim okulu müdürlerinin öğretim programın yönetme görevlerini yerine getirme miktarının belirlenmesi. [Yayımlanmamış yüksek lisans tezi]. Yıldız Teknik Üniversitesi.

Burger, J. M. (2006). Kişilik. (Çeviren: Erguvan Sarığlu) (1. baskı). Kaknüs Yayınları.

Buyrukçu, F. (2007). Sınıf öğretmenlerinin öğretimsel liderlik rolleri. [Yayımlanmamış yüksek lisans tezi]. Abant İzzet Baysal Üniversitesi.

Büyüköztürk, Ş., Kılıç-Çakmak, E., Akgün, Ö., Karadeniz, Ş., \& Demirel, F. (2016). Bilimsel araştırma yöntemleri. Pegem Akademi Yayınc1lik. https://doi.org/10.14527/9789944919289

Can, B. (2014). Ortaokul müdürlerinin liderlik stilleri ile öğrenci başarısı arasındaki ilişki. [Yayımlanmamış yüksek lisans tezi]. Dokuz Eylül Üniversitesi.

Coad, A. F., \& Berry, A. J. (1998). Transformational leadership and learning orientation. Leadership $\mathcal{E}$ Organization Development Journal,19(3), 164-172. https://doi.org/10.1108/01437739810210211

Coşkun, H., \& Aslan, S. (2021). Kişilik özellikleri, duygusal dışavurum ve sosyal onay ihtiyacı kavramları üzerine bir derleme. Uluslararast Anadolu Sosyal Bilimler Dergisi, 5(1), 60-77. https://doi.org/10.47525/ulasbid.833342

Cunningham, W. G., \& Cordeiro, P. A. (2003). Educational leadership: A problem-based approach. Allyn ve Bacon/Longman publishing

Çelik, V. (2011). Eğitimsel liderlik. (5. Bask1). Pegem A Yayınc1lık.

Deniz, Ü., \& Erdener, M. A. (2016). Okul müdürlerinin sergilediği öğretimsel denetim davranışlarına ilişkin öğretmen görüşleri. Ö. K. Tüfekçi (Ed.), Sosyal bilimlerde stratejik araştırmalar içinde (ss. 69-81). Lambert Academic Publishing.

Erçetin, Ş. Ş. (2000). Lider sarmalında vizyon. Nobel Yayıncıllk.

Fiedler, F. (1996). Research on leadership selection and training. One View of The Future, Administrative Science Quarterly, 41(2), 241-250. https://doi.org/10.2307/2393716

Fraenkel, J. R. Wallen, N. E., \& Hyun, H. (2012). How to design and evaluate research in education (8. bs). McGrawHill.

Gedikoğlu, T., \& Tahaoğlu F. (2009). İlköğretim okulu müdürlerinin liderlik rolleri. Kuram ve Uygulamada Eğitim Yönetimi, 15(58), 277-294.

Glanz, J. (2006). Instructional leadership. Corwin Press.

Gülbahar, B., \& Özdemir, S. (2019). Okul yöneticilerinin öğretim programlarının uygulanmasındaki 
öğretimsel liderlik rollerine ilişkin öğretmen algılarının incelenmesi. YYÜ Eğitim Fakültesi Dergisi, 16(1), 1759-1790. https://doi.org/10.23891/efdyyu.2019.179

Gümüşeli, A.İ. (1996). Okul müdürlerinin öğretim liderliğini sınırlayan etkenler. Kuram ve Uygulamada Ĕ̆itim Yönetimi Dergisi, 2(2), 202-211.

Hallinger, P., \& Murphy, J. (1985). Assessing the instructional management behavior of principals. The Elementary School Journal, 86(2), 217-247. https://doi.org/10.1086/461445

Horng, E., \& Loeb, S. (2010). New thinking about instructional leadership. Phi Delta Kappan, 92, 66-69. https://doi.org/10.1177/003172171009200319

Huck, S. W. (2008). Reading statistics and research (5. bs). Pearson.

İlğan, A. (2013). Öğretmenler için etkili mesleki gelişim faaliyetleri. Uşak Üniversitesi Sosyal Bilimler Dergisi, Özel Sayl, 41-56. https://doi.org/10.12780/UUSBD174

İnandı, Y., \& Özkan, M. (2006). Resmi ilköğretim okulları ve liselerde görev yapan yönetici ve öğretmenlerin görüşlerine göre müdürler ne derece öğretim liderliği davranışları göstermektedir? Mersin Üniversitesi Eğitim Fakültesi Dergisi, 2(2), 123-149.

İnceler, S. (2005). İlköğretim okulu yöneticilerinin öğretmenlerin mesleki gelişimlerine yönelik öğretimsel liderlik davranışları. [Yayımlanmamış yüksek lisans tezi]. Abant İzzet Baysal Üniversitesi.

Jaiswal, N. K., \& Dhar, R. L. (2015). Transformational leadership, innovation climate, creative self-efficacy and employee creativity: A multilevel study. International Journal of Hospitality Management, 51, 30-41. https://doi.org/10.1016/j.ijhm.2015.07.002

Johnson, W., \& Synder, K. J. (1990). Leadership for productive schools. https://eric.ed.gov/?q=snyder\&ff1=subInstructional+Leadership\&id=ED329014

Karasar, N. (2014). Bilimsel araştırma yöntemleri. Nobel

Kaya, M., \& Yiğit, B. (2020). Okul yöneticilerin öğretimsel liderlik davranışlarının incelenmesi. Academic Platform Journal of Education and Change, 3(1), 79-90.

Kurt, E. (2020). Okul müdürlerinin öğretimsel liderlik davranışlarn ile sınıf rehber öğretmenlerinin rehberlik uygulamaları arasındaki ilişki [Yayımlanmamış yüksek lisans tezi]. Karamanoğlu Mehmetbey Üniversitesi.

Marks, H. M., \& Printy, S. M. (2003). Principal leadership and school performance: An integration of transformational and instructional leadership. Educational Administration Quarterly, 39(3), 370- 397. https://doi.org/10.1177/0013161X03253412

Milli Eğitim Bakanlı̆̆1 $\quad$ (2005). $\quad$ Müfredat geliştirme süreci. http://ttkb.meb.gov.tr/programlar/program giris/görevler 5.htm

Moore, D. R. (2015). Master teachers as instructional leaders: An instrumental case study [Unpublished doctoral thesis]. Liberty University.

Özalp, İ., \& Öcal, H. (2000). Örgütlerde dönüştürücü (transformational) liderlik yaklaşımı. Balıkesir Üniversitesi Sosyal Bilimler Enstitüsü Dergisi, 3(4), 207-227.

Özdemir, E. (2003). Liderlik ve etik. Uludă̆ Üniversitesi İktisadi ve İdari Bilimler Dergisi, 12(2), 151-168.

Özdemir, S. M. (2016). Öğretmen niteliğinin bir göstergesi olarak sürekli mesleki gelişim. Gazi Ĕ̆itim Bilimleri Dergisi, 2(3), 233-244.

Özdemir, M. (2018). Ĕ̆̆itim yönetimi: Alanın temelleri ve çă̆daş yönelimler. Anı Yayınları. https://doi.org/10.14527/9786052415306.03

Özdemir, Y., Buyruk, H., \& Güngör, S. (2018). Öğretmen adaylarının eleştirel düşünme eğilimi ile liderlik 
Öğretmenlerin Bakış Açısından Okul Yöneticilerinin Öğretimsel...

yönelimleri arasındaki ilişki. Mersin Üniversitesi Ĕ̆itim Fakültesi Dergisi, 14(2), 548-571. https://doi.org/10.17860/mersinefd.434785

Özkaynak Topaçoğlu, D., \& Şahin Firat, N. (2016). İlköğretim okul müdürlerinin öğretimsel liderlik davranışları, Turkish Studies -International Periodical for the Languages, Literature and History of Turkish or Turkic-, 11(3), 1849-1878. https://doi.org/10.7827/TurkishStudies.9377

Prytula, M., Noonan, B., \& Hellsten, L. (2013). Toward instructional leadership: principals' perceptions of large-scale assessment in schools. Canadian Journal of Educational Administration and Policy, 140(12), 1-30.

Somer, O. (1998). Türkçe'de kişilik özelliği tanımlayan sıfatların yapısı ve beş faktör modeli. Psikoloji Dergisi, 13(42), 17-32.

Şahin, C., \& Demir, F. (2015). Değişim çağında okul yöneticilerinin okullardaki eğitim teknolojilerini yönetme becerilerinin incelenmesi. Uluslararası Sosyal Araştırmalar Dergisi, 8(39), 717-725. https://doi.org/10.17719/jisr.20153913792

Şişman, M. (2011). Öğretim liderliği. Pegem Akademi.

Şişman, M., \& Turan, S. (2004). Eğitim ve okul yönetimi. Yüksel Özden (Ed.). Eğitim ve okul yöneticiliği el kitabı içinde (ss. 99-146). Pegem A Yayıncilık.

Şümür, İ. (2021). Öğretmenlerin yöneticilerinin öğretimsel liderlik davranışlarına yönelik algıları [Tezsiz yüksek lisans projesi]. Pamukkale Üniversitesi.

Tahaoğlu, F., \& Gedikoğlu, T. (2009). İlköğretim okulu müdürlerinin liderlik rolleri. Kuram ve Uygulamada Eğitim Yönetimi, 15(58), 274-298.

Yılmaz, E., \& Kurşun, A.T (2015). Okul müdürlerinin öğretimsel liderlik davranışları ile öğretmenlerin akademik iyimserlik düzeyleri arasındaki ilişki. Çağdaş Yönetim Bilimleri Dergisi, 1(1), 35-48.

Yükseköğretim Kurulu. (1998). Eğ̈itim fakültesi öğretmen yetiştirme lisans programları. https://www.yok.gov.tr/kurumsal/idari-birimler/egitim-ogretim-dairesi/ogretmen-yetistirme 


\section{EXTENDED ABSTRACT}

\section{Introduction}

The school is a common living space where many stakeholders should work in cooperation, and education and training are conducted. There are many components in a school environment. Because of this, schools are under the pressure of both their internal and external environments. Therefore, a very dynamic structure emerges in the school environment. On the other hand, different goals are determined due to the great number of components that a school has. The diversity of the goals has both positive and negative aspects. First of all, the diversity of goals creates the problem of integration in the school and brings the management difficulty to the agenda. For this reason, the concept of leadership becomes very important. Leaders with distinctive skills, who can use the resources of the school effectively and efficiently in line with the needs and make a difference in management, can also make it easier to ensure the effectiveness of the education and training process. In this study, it is aimed to make a general evaluation of the instructional leadership competencies of school administrators according to the perspectives of teachers working in different school types.

\section{Method}

In this study, which was designed as survey method, both single and correlational survey were employed. 252 teachers in different branches, working in different regions and in different school types in Turkey in 2020-2021 academic year participated in the study. Descriptive statistics were used to determine the instructional leadership competencies of school administrators. In addition, evaluation intervals were determined to determine the general tendencies of school administrators regarding instructional leadership competencies.

\section{Results}

According to the perspectives of teachers, the mean score of instructional leadership competences of school administrators were found as $\bar{X}=3.28$. Therefore, it can be said that school administrators exhibit behaviors related to instructional leadership from time to time. Additionally, instructional leadership competences of school administrators were found to differ significantly according to the gender of teachers $[t(250)=-2.146, p<.05]$. Accordingly, there was a statistically significant difference between the perspectives of male teachers on the instructional leadership competences of school administrators $(\bar{X}=3.43)$ and the perspectives of female teachers $(\bar{X}=3.17)$.

Instructional leadership competencies of school administrators did not show a statistically significant difference according to the school type that the teachers worked in $[F(3-248)=1.441, p>.05]$. It was also found that instructional leadership competencies of school administrators did not show a statistically significant difference according to the year of experience variable $[F(5-251)=2.029, p>.05]$. In other words, teachers' views on the instructional leadership competencies of school administrators did not differ significantly depending on the teachers' years of experience.

When the perspectives of teachers on the instructional leadership of school administrators were examined in terms of personality traits of teachers, it was found that teachers with more positive personal characteristics were in the opinion that school administrators had higher instructional leadership competences. In addition, according to the results of the independent sample t-test, there was a statistically significant difference between the opinions of the teachers in terms of agreeableness personality trait $[t(134)=$ $-2.378, p<.05]$.

\section{Conclusion}

According to the perspectives of teachers working in different school types, school administrators exhibit behaviors related to instructional leadership from time to time. When the total mean score and the scores obtained from the sub-dimensions of the scale were evaluated, it was seen that school administrators exhibited behaviors to encourage learning most of the time, and exhibited the behaviors in other sub- 
dimensions occasionally.

According to the opinions of the teachers, school administrators were least likely to exhibit behaviors towards supervising and evaluating the teaching. The reason why school administrators exhibit instructional supervision and evaluation roles less than their roles in other sub-dimensions may be that supervision of teachers is perceived negatively in education, as in each business sector in Turkey, and it makes them feel uncomfortable. Therefore, it can be assumed that school administrators do not want to fulfill their supervisory role in order to avoid conflicts with teachers, and that administrators do not spare enough time for supervision and evaluation.

According to the gender of the teachers, the instructional leadership competencies of the school administrators showed a significant difference. This finding is different from the research results of Yllmaz and Kurşun (2015), which indicated that the instructional leadership competencies of school administrators do not show a significant difference according to the gender of the teachers. The reason for the difference between these two results can be interpreted as the fact that the perceptions of the teachers participating in the research and their understanding of the process may have changed over time.

Instructional leadership competencies of school administrators did not show a statistically significant difference according to the school type that the teachers work in. Instructional leadership competencies should emerge similarly in administrators working in different school types. We can assume that teachers working in different school types have similar opinions on the school administrators in terms of their instructional leadership competencies, and the school administrators working in different schools exhibit similar behaviors. That is, school type is not seen as a factor that reveals instructional leadership competencies.

The perspectives of teachers on the instructional leadership competencies of school administrators did not differ significantly depending on the years of experience variable. However, an important finding obtained from the total mean score and the sub-dimensions of the scale showed that teachers with 26 or more years of experience were in the opinion that the school administrators were less likely to exhibit the behaviors related to their instructional leadership competencies. This can be associated with the pedagogical formation education taken by those who became teacher before 2000 .

As a result of the study, teachers who exhibited positive personality traits (agreeableness, extroversion, consistent emotional state, high level self-control, openness to development) evaluated school administrators' competencies regarding instructional leadership more positively than those who did not. This can be explained by the fact that people with positive personality traits are more comfortable while expressing their positive emotions compared to those who have negative emotions, and they evaluate more positively. 